\title{
Effect of Heat on Antioxidant Activity of Some Tropical Leafy Vegetables
}

\author{
*1S.O. Nwozo, 1 B.J. Oso, and 1,2B.E. Oyinloye \\ ${ }^{1}$ Nutritional and Industrial Research Laboratories, Department of Biochemistry, Faculty of Basic Medical Science, \\ College of Medicine, University of Ibadan, Ibadan, Nigeria. \\ 2Department of Biochemistry, College of Science, Afe Babalola University, Ado Ekiti, Nigeria. \\ [Corresponding author: sonwozo@yahoo.com; : : +234-802-3658-268]
}

\begin{abstract}
The present study examined the effect of different cooking times on total phenolics, total flavonoids, ascorbic acid content and antioxidant properties of seven tropical leafy vegetables: Pterocarpus mildbraedii, Gongronema latifolium, Ocimum gratissimum, Solanecio biafrae, Piper guineense, Celosia argentea and Solanum melongena. The thermal treatments employed were both long simmer (20 minutes at $80^{\circ} \mathrm{C}$ ) and short simmer $\left(5\right.$ minutes at $\left.80^{\circ} \mathrm{C}\right)$. The result show that both short and long simmer results to a significant decrease $(P<0.05)$ in the ascorbic acid content in all the vegetables. There was a significant increase in the total phenol, total flavonoid, DPPH radical scavenging ability, reducing property, $\mathrm{Fe}^{2+}$ chelating ability and hydroxyl radical scavenging ability. In like manner, short simmer treatment enhances the total antioxidant activities of all the vegetables. These results suggest that although thermal treatments enhances the nutritional value of vegetables by increasing the bio-accessible phenolic content and total antioxidant activity, long simmer treatment results in the disruption of the phytochemicals constituents present. The study therefore concludes that short time simmer treatment may result to optimum yield of antioxidant activities in leafy vegetables.
\end{abstract}

Keywords: Antioxidant activity, Ascorbic acid, Leafy vegetables, Total flavonoids, Total phenolics.

\section{INTRODUCTION}

There has been an increase in understanding the interplay between free radicals and antioxidants in maintaining human health (Rahman, 2007; Lobo et al., 2010). Free radicals especially reactive oxygen species (ROS) has been implicated in the pathogenesis of certain human diseases such as hypertension, diabetes mellitus, cancer, aging, atherosclerosis, chronic arterial disease and neurodegenerative disorders (Moskovitz et al., 2002; Rahman, 2007; Valko et al., 2007). ROS are highly reactive molecules that are naturally and constantly generated in small amounts during the body's normal metabolic reactions and can react with and damage complex molecules such as lipids, proteins and DNA (Cederbaum, 2009).

It has been established that ROS can be both harmful and beneficial in biological systems. Obvious examples of their beneficial effectwould be their role in immune defense, antibacterial action, vascular tone, and signal transduction (Gutowski, 2013). In contrast, high concentrations of ROS can cause damage to cell structures, including lipids and membranes, proteins and nucleic acids; this damage is often referred to as "oxidative stress" (Poli et al., 2004). Hence, much attention has been focused on the use of antioxidants, especially natural antioxidants, as the most efficient way to inhibit lipid peroxidation, or to protect against the damage caused by free radicals, thus preventing tissue injuries, health risks and undesired transformations which can be typified as tumour (Vendemiale et al., 1999).

High consumption of vegetables and fruits is associated with a lowered incidence of certain human diseases and aging. The protective effect of these vegetables and fruits has been attributed to the presence of high biological active constituents they contain which impacts health beyond ordinary nutrition (Cartea et al., 2010). Among the biologically active constituents, natural antioxidants have attracted interest because of their safety and potential therapeutic effect. These antioxidants are capable of acting as free radical scavengers, peroxide decomposers, singlet oxygen quenchers, enzyme inhibitors and synergists (Rufino et al., 2010). However, several studies have reported that the majority of the antioxidant activity may be from compounds such as flavonoids, isoflavone, flavones, anthocyanin, catechin and isocatechin, which are 
phenolic derivatives rather than from vitamins $C, E$ and $\beta$ - carotene (Yang et al., 2002, Sun et al., 2002).

In Nigeria there are several varieties of edible leafy vegetables used by indigenous people as part of their daily diets or as traditional medicines and most of these vegetables undergo a cooking process rather than being eaten raw. Cooking is usually carried out in order to increase and improve the palatability and edibility of these vegetables.

Therefore, the present study was designed to examine the effect of different cooking time on total phenolics, total flavonoids, ascorbic acid content and antioxidant properties of seven tropical leafy vegetables namely: Pterocarpus mildbraedi, Gongronema latifolium, Ocimum gratissimum, Solanecio biafrae, Piper guineense, Celosia argentea and Solanum melongena.

\section{MATERIAL AND METHODS}

Analytical grade chemicals/reagents were used for the study. All spectrophotometric analyses were performed on Unico (1200) Spectrophotometer. Filter paper (Whatman grade 1) and Electrical Thermostatic Water Bath Boiler (Grant Y14).

\section{Sampling Procedure}

Fresh samples of Pterocarpus mildbraedii, Gongronema latifolium, Ocimum gratissimum, Solanecio biafrae, Piper guineense, Celosia argentea and Solanum melongena were purchased from Sango Elewure market, Ibadan (South western, Nigeria). They were stored at $4^{\circ} \mathrm{C}$ and used within four days of purchase. Identification and authentication was carried out by Mr. D. Esimekhuai at the Herbarium of the Department of Botany, University of Ibadan, Ibadan, Nigeria and voucher specimens were deposited at the Departmental Herbarium.

\section{Sample Preparation}

Fresh green leafy vegetables were rinsed in water. The leafy portions were removed from the thick stalks and sliced into almost equal small pieces. The sliced vegetables were separated into three different portions through random sampling and each portion was randomly assigned into one of the three treatments: uncooked, short simmer and long simmer. $20 \mathrm{~g}$ of the sample was assigned to the uncooked group, and $200 \mathrm{ml}$ of distilled water was added to it; for the short simmer, $20 \mathrm{~g}$ of sample were added to $200 \mathrm{ml}$ of distilled water heated to $80^{\circ} \mathrm{C}$ and cooked for 5 minutes whereas $20 \mathrm{~g}$ of samples were cooked in
$200 \mathrm{ml}$ of $80^{\circ} \mathrm{C}$ distilled water for 20 minutes for the long simmer allotment. The uncooked, short simmered and long simmered samples of the green vegetables were then homogenizedrespectively; each mixture was then filtered using filter paper. The filtrates were stored in the refrigerator (less than $3^{\circ} \mathrm{C}$ ) for subsequent analysis.

\section{Radical Scavenging Activity Using DPPH Method} The free radical scavenging ability of the extracts against DPPH (1,1-diphenyl-2 picrylhydrazyl) free radical was evaluated as described by Ardestani and Yazdanparast (Ardestani and Yazdanparast, 2007). For each reading, $150 \mu \mathrm{l}$ of sample were added to 850 $\mu \mathrm{l}$ of $50 \%$ (v/v) ethanol. To this $1 \mathrm{ml}$ of $0.2 \mathrm{mM} \mathrm{DPPH}$ in $50 \%$ (v/v) ethanol solution was added. Mixtures were then shaken and held for 30 minutes at room temperature $\left(25^{\circ} \mathrm{C}\right)$ after which, absorbance readings were recorded at $517 \mathrm{~nm}$. Absorbance readings were compared to a negative control of $50 \%$ (v/v) ethanol and result expressed as a percentage change per sample concentration $(\mathrm{mg} / \mathrm{ml})$ according to the following formula:

Free radical scavenging activity $(\%)=\left[\left(A_{0}-A_{1}\right) / A_{0}\right] \times$ $100 \%$,

where $A_{0}$ was the absorbance of the control, $A_{1}$ was the absorbance of sample.

\section{Hydroxyl Radical Scavenging Activity Assay}

The scavenging activity for hydroxyl radicals is measured with Fenton reaction as described by Yu et al. (2004). Reaction mixture contained $60 \mu \mathrm{L}$ of $1.0 \mathrm{mM}$ $\mathrm{FeCl}_{2}, 90 \mu \mathrm{l}$ of $1 \mathrm{mM}$ 1,10-phenanthroline, $2.4 \mathrm{~mL}$ of 0.2 $\mathrm{M}$ phosphate buffer ( $\mathrm{pH} 7.8), 150 \mu \mathrm{L}$ of $0.17 \mathrm{M} \mathrm{H}_{2} \mathrm{O}_{2}$, and $1.5 \mathrm{~mL}$ of extracts. $\mathrm{H}_{2} \mathrm{O}_{2}$ was added to start the reaction, this was incubated at room temperature for 5 $\mathrm{min}$, and the absorbance of the mixture was measured at $560 \mathrm{~nm}$ with a spectrophotometer. The hydroxyl radicals scavenging activity was calculated using $\%$ Inhibition $=\left[\left(A_{0}-A_{1}\right) / A_{0} \times 100\right]$,

where $A_{0}$ was the absorbance of the control (blank, without extract) and $A_{1}$ was the absorbance in the presence of the extract.

\section{Reducing Power Assay}

The reducing property of the extracts was determined spectrometrically as described by Oyaizu (1986). The extract $(2.5 \mathrm{ml})$ was mixed with $2.5 \mathrm{ml}^{\circ} 200 \mathrm{mmol} \mathrm{I}^{-1}$ sodium phosphate buffer ( $\mathrm{pH} 6.6)$ and $2.5 \mathrm{ml}$ of $1 \%$ potassium ferricyanide. The mixture was incubated at 
$50^{\circ} \mathrm{C}$ for $20 \mathrm{~min}$ and then $2.5 \mathrm{ml}$ of $10 \%$ trichloroacetic acid (TCA) was added. This mixture was centrifuged at $650 \mathrm{rpm}$ for $10 \mathrm{~min}, 5 \mathrm{ml}$ of the supernatant was mixed with an equal volume of water and $1 \mathrm{ml}$ of $0.1 \%$ ferric chloride. The absorbance was measured at $700 \mathrm{~nm}$. The ferric reducing antioxidant property was subsequently calculated using ascorbic acid as standard and the resultwas expressed in ascorbic acid equivalent per $100 \mathrm{~g}$ of the fresh sample.

\section{$\mathrm{Fe}^{2+}$ Chelation Assay}

The chelating activity of the extracts for ferrous ions $\mathrm{Fe}^{2+}$ was measured according to the method described by Dinis et al. (1994). Deionized water $(1.6 \mathrm{ml})$ was added to $0.5 \mathrm{~mL}$ of the extract, subsequently, $0.05 \mathrm{ml}$ of $\mathrm{FeCl}_{2}(2 \mathrm{mM})$ was added to solution and $0.1 \mathrm{ml}$ ferrozine $(5 \mathrm{mM})$ was added after $30 \mathrm{~s}$. Ferrozine reacted with the divalent iron to form stable magenta complex species that were very soluble in water. After $10 \mathrm{~min}$ at room temperature, the absorbance of the $\mathrm{Fe}^{2+}-\mathrm{Ferrozine}$ complex was measured at $562 \mathrm{~nm}$. The chelating activity of the extract for $\mathrm{Fe}^{2+}$ is calculated as:

Chelating rate $(\%)=\left[\left(A_{0}-A_{1}\right) / A_{0}\right] \times 100 \%$, where $A_{0}$ is the absorbance of the control (blank, without extract) and $A_{1}$ is the absorbance in the presence of the extract.

\section{Estimation of Total Phenol Content}

The total phenolic content in the extract was measured using Folin-Ciocalteu reagent based on the methods described by Singleton et al. (1999). $0.5 \mathrm{ml}$ of the extract $(10 \mathrm{mg} / 100 \mathrm{ml})$ was mixed with $1.5 \mathrm{ml}(1: 10 \mathrm{v} / \mathrm{V}$ diluted with distilled water) Folin-Ciocalteu's reagent and allowed to stand for $25^{\circ} \mathrm{C}$ for $5 \mathrm{~min}$. Then $2 \mathrm{ml}$ of sodium carbonate $\left(\mathrm{Na}_{2} \mathrm{CO}_{3}, 7.5 \%\right.$, w/v) was added and the mixture were allowed stand for another $90 \mathrm{~min}$ and kept in the dark with intermittent shaking. The absorbance of the colour formed was measured at 725 $\mathrm{nm}$ using a spectrophotometer. A standard curve was obtained using a freshly made Gallic acid solution with varying degrees of concentration in place of samples. The results were expressed in $\mathrm{mg} / 100 \mathrm{~g}$ of the fresh sample.

\section{Total Flavonoid Assay}

The method described by Jagadish et al. (2009) was used for the determination of total flavonoid content. One milliliter of the was added to $10 \mathrm{ml}$ volumetric flask containing $4 \mathrm{ml}$ of distilled water. To the above mixture, $0.3 \mathrm{ml}$ of $5 \% \mathrm{NaNO}_{2}$ was added. After 5 minutes, 0.3 $\mathrm{ml}$ of $10 \% \mathrm{AlCl}_{3}$ was added. At 6 th $\mathrm{min}, 2 \mathrm{ml}$ of $1 \mathrm{M}$
$\mathrm{NaOH}$ was added and the total volume was made up to $10 \mathrm{ml}$ with distilled water. The solution was mixed well and the absorbance was measured against prepared reagent blank at $510 \mathrm{~nm}$. Total flavonoid content of the extract was expressed as percentage of catechin equivalent per $100 \mathrm{~g}$ of fresh mass.

\section{Ascorbic Acid Content Determination}

Dichlorophenolindophenol, a redox dye, was used as an indicator for ascorbic acid as described by VanderJagt et al. (1986). The extract $(2 \mathrm{ml})$ was acidified with $2 \mathrm{ml}$ of $0.5 \%$ glacial acetic acid and the mixture was shaken for 5 minutes at room temperature. $0.1 \mathrm{M} \mathrm{2,6-dichlorophenolindophenol} \mathrm{was}$ titrated into the acidified extract until permanent pink color was obtained. The result was expressed in $\mathrm{mg} / 100 \mathrm{~g}$ of the fresh sample.

\section{Statistical Analysis}

All data were reported as mean \pm standard deviation of triplicate determinations and analyzed using one-way analysis of variance (ANOVA) with a Fisher's Least Significant Difference post hoc test to determine significant differences $(p<0.05)$ between treatments using Statistical Package for Social Science Research version 17 (SPSS). The data were correlated using Pearson correlation coefficient at $p<0.05$.

\section{RESULTS}

\section{1,1-Dipheynl-2-picrylhydrazyl (DPPH) Radical Scavenging Activity}

Results of the current study (Table 1) revealed that DPPH radical scavenging ability of the vegetables increased significantly $(P<0.05)$ with short simmer treatment in all the vegetables with the highest increase observed in O. gratissimum. There was also a significant increase $(p<0.05)$ in antioxidant activity during the long simmer treatment in all the vegetables with an exception in P. mildbraedii and C. argentea whose antioxidant activity decreased significantly $(p<0.05)$.

\section{Hydroxyl Radical Scavenging Ability}

The activity of each of the vegetable extracts on hydroxyl radical is shown in Table 2 . The results showed that the short simmer produced significant increase $(p<0.05)$ in the antioxidant activity with $S$. biafrae $(59.25 \%)$ having the highest increase. During the long simmer treatment, significant increase $p<0.05$ ) was observed for $P$. mildbraedii, G. latifola, S. biafrae, and $S$. melongena. Conversely, a significant $(p<0.05)$ 
decrease was observed for both $P$. guineense and $O$. gratissimum.

\section{Reducing Power Activity}

The reducing power activity of the extracts is shown in Table 3. The results revealed that short simmer on the vegetable extract of $P$. mildbraedii, $S$. biafrae and $P$. guineense, $S$. melongena had a significant higher reducing power $(P<0.05)$ than the corresponding uncooked extracts with $S$. biafrae showing the highest percentage increase (82.83\%). However, long simmer on the vegetable extracts of $S$. biafrae and $P$. guineense showed significant increase $(P<0.05)$ in the reducing ability. Significant reduction $(P<0.05)$ was observed in the long simmer extracts of $G$. latifola, $C$. argentea and S. melongena when compared with the uncooked.

\section{Total Phenol Content (TPC)}

The treatments resulted in differences in TPC for all the vegetables with the short simmered $P$. mildbraedii containing the highest amount of Gallic acid equivalents of polyphenolics (Table 4). The total phenol content of the uncooked leafy vegetables ranged from $186.26 \pm 3.72 \mathrm{mg} / 100 \mathrm{~g}$ (P. mildbraedii) to $547.75 \pm 15.06 \mathrm{mg} / 100 \mathrm{~g}$ (S. malongena) while the TPC of the short simmer and long simmer ranged respectively from $233.13 \pm 1.931 \mathrm{mg} / 100 \mathrm{~g}(P$. mildbraedii) to $639.06 \pm 5.61 \mathrm{mg} / 100 \mathrm{~g}$ (S. malongena) and $123.27 \pm 4.30$ (S. biafrae) to $619.52 \pm 3.88$ (P. mildbraedii). There was a significant increase $(P<$ 0.05 ) in the Gallic acid equivalents between the uncooked, long simmer and the short simmer for all the vegetables studied except $C$. argentea.

\section{Total Flavonoid Content}

The total flavonoid content, reported as Catechin equivalent antioxidant capacity, is presented in Table 5. The total flavonoid content of the uncooked vegetables ranged from $11.70 \pm 0.24 \mathrm{mg} / 100 \mathrm{~g}$ ( $\mathrm{G}$. latifola) to $48.72 \pm 0.14 \mathrm{mg} / 100 \mathrm{~g}$ ( $P$. mildbraedii ), while the flavonoids content of short simmered vegetables ranged from $17.60 \pm 0.19 \mathrm{mg} / 100 \mathrm{~g}$ (G. latifola) to $59.98 \pm 0.51 \mathrm{mg} / 100 \mathrm{~g}$ (P. mildbraedii ), and the long simmered ranged from $17.19 \pm 0.01 \mathrm{mg} / 100 \mathrm{~g}$ (G. latifola) to $57.29 \pm 0.43$ (mg/100 g (P. mildbraedii). When vegetables were subjected to short simmer treatment, G. latifola showed the highest increase $(58.80 \%)$ with significant differences $(P<0.05)$. The rest of the vegetables also showed significant differences $(P<0.05)$ with increase ranging between $10.61 \%$ and $58 \%$. After long simmer treatment, the vegetables significantly increased $(P<0.05)$ catechin equivalent antioxidant capacity with respect to the uncooked products except 0 . gratissimum which showed significant differences $(P<0.05)$ with mean loss of around $4.92 \%$.

\section{$\mathrm{Fe}^{2+}$ - Chelating Activity}

The formation of the ferrozine - $\mathrm{Fe}^{2+}$ complex was interrupted in the extracts, indicating their chelating activity as presented in Table 6 . The treatment that was able to chelate the greatest amount of $\mathrm{Fe}^{2+}$ was the short simmer extracts for all the vegetables except $C$. argentea in which the long simmer extract had the highestchelating activity. Significantincrease $(P<0.05)$ was observed in all during long simmer treatment except $P$. mildbraedii, where there was no significant difference $(p>0.05)$ and $S$. biafrae which showed a significant reduction $(p<0.05)$ with percentage loss of $27.93 \%$.

\section{Ascorbic Acid Content}

The results of ascorbic acid content (Table 7) revealed that cooking causes a significant decrease $(P<0.05)$ in the ascorbic acid content (vitamin $\mathrm{C}$ ) in all the vegetables used.

Table 1: 1,1-Dipheynl-2-picrylhydrazyl (DPPH) radical scavenging (\%) by vegetables subjected to different cooking treatments.

\begin{tabular}{llll}
\hline Vegetables & Uncooked & Short Simmer & Long Simmer \\
\hline P. mildbraedii & $66.73 \pm 0.28^{\mathrm{a}}$ & $82.15 \pm 0.35^{\mathrm{b}}$ & $58.89 \pm 0.28^{\mathrm{c}}$ \\
G. latifola & $31.40 \pm 0.30^{\mathrm{a}}$ & $51.24 \pm 0.65^{\mathrm{b}}$ & $43.41 \pm 0.30^{\mathrm{c}}$ \\
O. gratissimum & $33.95 \pm 0.35^{\mathrm{a}}$ & $77.66 \pm 0.74^{\mathrm{b}}$ & $73.98 \pm 0.20^{\mathrm{c}}$ \\
S. biafrae & $44.63 \pm 0.37^{\mathrm{a}}$ & $74.08 \pm 0.14^{\mathrm{b}}$ & $53.52 \pm 0.32^{\mathrm{c}}$ \\
P. guineense & $48.57 \pm 0.42^{\mathrm{a}}$ & $86.02 \pm 0.05^{\mathrm{b}}$ & $68.62 \pm 0.72^{\mathrm{c}}$ \\
C. argentea & $66.35 \pm 0.26^{\mathrm{a}}$ & $77.91 \pm 1.42^{\mathrm{b}}$ & $58.95 \pm 0.31^{\mathrm{c}}$ \\
S. melongena & $34.45 \pm 0.30^{\mathrm{a}}$ & $70.47 \pm 0.16^{\mathrm{b}}$ & $72.45 \pm 0.62^{\mathrm{c}}$ \\
\hline Each mean represents analyses of three independent samples. Statistical differences were analyzed by ANOVA $(\mathrm{P}<0.05)$. Different letter superscipits within a row indicate significant differences at $\mathrm{p}<0.05$.
\end{tabular}


Table 2: Hydroxyl radical scavenging (\%) by vegetables subjected to different cooking treatments.

\begin{tabular}{llll}
\hline Vegetables & Uncooked & Short Simmer & Long Simmer \\
\hline P. mildbraedii & $60.21 \pm 0.47^{\mathrm{a}}$ & $74.16 \pm 0.30^{\mathrm{b}}$ & $62.13 \pm 0.32^{\mathrm{c}}$ \\
G. latifola & $32.55 \pm 0.50^{\mathrm{a}}$ & $50.91 \pm 1.80^{\mathrm{b}}$ & $39.48 \pm 0.73^{\mathrm{c}}$ \\
O. gratissimum & $56.57 \pm 0.57^{\mathrm{a}}$ & $58.77 \pm 0.43^{\mathrm{b}}$ & $46.96 \pm 0.12^{\mathrm{c}}$ \\
S. biafrae & $40.93 \pm 0.17^{\mathrm{a}}$ & $65.18 \pm 0.25^{\mathrm{b}}$ & $54.04 \pm 0.26^{\mathrm{c}}$ \\
P. guineense & $54.16 \pm 0.79^{\mathrm{a}}$ & $66.48 \pm 0.45^{\mathrm{b}}$ & $48.06 \pm 0.34^{\mathrm{c}}$ \\
C. argentea & $57.34 \pm 0.34^{\mathrm{a}}$ & $69.26 \pm 0.74 \mathrm{~b}$ & $54.57 \pm 0.30^{\mathrm{b}}$ \\
S. melongena & $50.62 \pm 1.78^{\mathrm{a}}$ & $61.54 \pm 0.52^{\mathrm{b}}$ & $54.44 \pm 0.46^{\mathrm{c}}$ \\
\hline Each mean represents analyses of three independent samples. Statistical differen nees were analyzed by ANOVA $(\mathrm{P}<0.05)$. Different letter superscripts within a row indicate significant differences at $\mathrm{p}<0.05$.
\end{tabular}

Table 3: Reducing power activity (mg Ascorbic acid equivalent $/ 100 \mathrm{~g}$ ) of vegetables subjected to different cooking treatments.

\begin{tabular}{llll}
\hline Vegetables & Uncooked & Short Simmer & Long Simmer \\
\hline P. mildbraedii & $68.81 \pm 0.43^{\mathrm{a}}$ & $80.37 \pm 1.75^{\mathrm{b}}$ & $65.72 \pm 1.61^{\mathrm{a}}$ \\
G. latifola & $42.71 \pm 1.77^{\mathrm{a}}$ & $46.55 \pm 1.69^{\mathrm{a}}$ & $32.82 \pm 0.10^{\mathrm{c}}$ \\
O. gratissimum & $35.00 \pm .66^{\mathrm{ac}}$ & $41.00 \pm .32^{\mathrm{a}}$ & $33.49 \pm 1.09^{\mathrm{c}}$ \\
S. biafrae & $45.39 \pm 0.96^{\mathrm{a}}$ & $82.99 \pm 0.71^{\mathrm{b}}$ & $68.52 \pm 0.85^{\mathrm{c}}$ \\
P. guineense & $53.22 \pm 1.04^{\mathrm{a}}$ & $80.49 \pm 0.48^{\mathrm{b}}$ & $78.23 \pm 0.74^{\mathrm{b}}$ \\
C. argentea & $57.47 \pm 1.59^{\mathrm{a}}$ & $60.30 \pm 1.84^{\mathrm{a}}$ & $44.29 \pm 0.97^{\mathrm{c}}$ \\
S. melongena & $30.73 \pm 0.39^{\mathrm{a}}$ & $38.67 \pm 0.36^{\mathrm{b}}$ & $25.94 \pm 0.32^{\mathrm{c}}$ \\
\hline Each mean represents analyses of three independent samples. Statistical dffiferences were analyzed by $\mathrm{ANOV}(\mathrm{P}<0.05)$. Different letter superscipts within a row indicate significant differencos at $\mathrm{p}<0.05$.
\end{tabular}

Table 4: Total phenolic content (mg Gallic acid equivalent $/ 100 \mathrm{~g}$ ) of vegetables subjected to different cooking treatments.

\begin{tabular}{|c|c|c|c|}
\hline Vegetables & Uncooked & Short Simmer & Long Simmer \\
\hline P. mildbraedii & $547.75 \pm 15.06^{a}$ & $639.06 \pm 5.61^{b}$ & $619.52 \pm 3.88^{b}$ \\
\hline G. latifola & $191.07 \pm 8.13^{a}$ & $336.32 \pm 3.75^{b}$ & $226.12 \pm 3.76^{c}$ \\
\hline O. gratissimum & $241.24 \pm 6.89^{a}$ & $398.03 \pm 3.42^{b}$ & $387.42 \pm 8.58^{c}$ \\
\hline S. biafrae & $213.85 \pm 6.34^{a}$ & $288.61 \pm 4.70^{b}$ & $123.27 \pm 4.30^{c}$ \\
\hline P. guineense & $393.66 \pm 4.31^{a}$ & $447.74 \pm 2.21^{b}$ & $447.54 \pm 4.26^{b}$ \\
\hline C. argentea & $421.74 \pm 3.96^{a}$ & $431.79 \pm 3.64^{a}$ & $335.74 \pm 3.17 \mathrm{c}$ \\
\hline S. melongena & $186.26 \pm 3.72^{a}$ & $233.13 \pm 1.93 b$ & $222.90 \pm 2.28^{c}$ \\
\hline
\end{tabular}

Table 5: Total flavonoid content $(\mathrm{mg}$ catechin equivalent $/ 100 \mathrm{~g}$ ) of vegetables subjected to different cooking treatments

\begin{tabular}{llll}
\hline Vegetables & Uncooked & Short Simmer & Long Simmer \\
\hline P. mildbraedii & $48.72 \pm 0.14^{\mathrm{a}}$ & $59.98 \pm 0.51^{\mathrm{b}}$ & $57.29 \pm 0.43^{\mathrm{c}}$ \\
G. latifola & $11.70 \pm 0.24^{\mathrm{a}}$ & $18.58 \pm 0.13^{\mathrm{b}}$ & $24.09 \pm 0.12^{\mathrm{c}}$ \\
O. gratissimum & $26.40 \pm 0.14^{\mathrm{a}}$ & $29.20 \pm 0.18^{\mathrm{b}}$ & $25.10 \pm 0.15^{\mathrm{c}}$ \\
S. biafrae & $15.15 \pm 0.02^{\mathrm{a}}$ & $17.60 \pm 0.19^{\mathrm{b}}$ & $17.19 \pm 0.01^{\mathrm{c}}$ \\
P. guineense & $30.74 \pm 0.47^{\mathrm{a}}$ & $45.50 \pm 0.68^{\mathrm{b}}$ & $46.34 \pm 0.33^{\mathrm{b}}$ \\
C. argentea & $42.30 \pm 0.10^{\mathrm{a}}$ & $56.04 \pm 0.31^{\mathrm{b}}$ & $49.23 \pm 0.58^{\mathrm{c}}$ \\
S. melongena & $32.05 \pm 0.28^{\mathrm{a}}$ & $42.07 \pm 0.72^{\mathrm{b}}$ & $47.06 \pm 0.72^{\mathrm{c}}$ \\
\hline Each mean represents analyses of three independent samples. Statistical differences were analyzed by ANOVA $(\mathrm{P}<0.05)$. Different letter superscipits within a row indicate significant differences at $\mathrm{p}<0.05$.
\end{tabular}


Table 6: Ferrous ion chelating activity (\%) of vegetables subjected to different cooking treatments.

\begin{tabular}{llll}
\hline Vegetables & Uncooked & Short Simmer & Long Simmer \\
\hline P. mildbraedii & $57.09 \pm 0.49^{\mathrm{a}}$ & $72.40 \pm 0.82^{\mathrm{b}}$ & $56.88 \pm 0.89^{\mathrm{a}}$ \\
G. latifola & $32.84 \pm 0.73^{\mathrm{a}}$ & $57.74 \pm 0.84^{\mathrm{b}}$ & $46.94 \pm 0.42^{\mathrm{c}}$ \\
O. gratissimum & $35.64 \pm 0.94^{\mathrm{a}}$ & $57.78 \pm 0.57^{\mathrm{b}}$ & $42.43 \pm 0.25^{\mathrm{c}}$ \\
S. biafrae & $44.79 \pm 1.63^{\mathrm{a}}$ & $73.76 \pm 0.69^{\mathrm{b}}$ & $32.28 \pm 0.30^{\mathrm{c}}$ \\
P. guineense & $42.52 \pm 0.24^{\mathrm{a}}$ & $63.81 \pm 1.05^{\mathrm{b}}$ & $54.84 \pm 0.53^{\mathrm{c}}$ \\
C. argentea & $48.74 \pm 0.26^{\mathrm{a}}$ & $64.21 \pm 0.87^{\mathrm{b}}$ & $66.57 \pm 0.43^{\mathrm{c}}$ \\
S. melongena & $31.04 \pm 0.47^{\mathrm{a}}$ & $61.42 \pm 0.38^{\mathrm{b}}$ & $33.96 \pm 0.30^{\mathrm{c}}$ \\
\hline
\end{tabular}

Each mean represents analyses of three independent samples. Statistical differences were analyzed by ANOVA $(P<0.05)$. Different letter superscripts within a row indicate significant differences at $p<0.05$.

Table 7: Ascorbic acid content $(\mathrm{mg} / 100 \mathrm{~g})$ of vegetables subjected to different cooking treatments

\begin{tabular}{llll}
\hline Vegetables & Uncooked & Short Simmer & Long Simmer \\
\hline P. mildbraedii & $68.67 \pm 1.20^{\mathrm{a}}$ & $43.33 \pm 1.86^{\mathrm{b}}$ & $58.00 \pm 2.31^{\mathrm{c}}$ \\
G. latifola & $61.67 \pm 0.88^{\mathrm{a}}$ & $37.00 \pm 0.57^{\mathrm{b}}$ & $35.33 \pm 0.67^{\mathrm{b}}$ \\
O. gratissimum & $63.33 \pm 2.73^{\mathrm{a}}$ & $18.33 \pm 1.20^{\mathrm{b}}$ & $18.33 \pm 0.88^{\mathrm{b}}$ \\
S. biafrae & $105.67 \pm 1.76^{\mathrm{a}}$ & $56.47 \pm 1.44^{\mathrm{b}}$ & $47.74 \pm 0.63^{\mathrm{b}}$ \\
P. guineense & $89.67 \pm 2.91^{\mathrm{a}}$ & $61.67 \pm 0.88^{\mathrm{b}}$ & $53.17 \pm 0.73^{\mathrm{c}}$ \\
C. argentea & $79.67 \pm 1.20^{\mathrm{a}}$ & $65.00 \pm 1.15^{\mathrm{b}}$ & $27.67 \pm 1.76^{\mathrm{c}}$ \\
S. melongena & $53.67 \pm 1.20^{\mathrm{a}}$ & $38.33 \pm 0.88^{\mathrm{b}}$ & $32.33 \pm 1.76^{\mathrm{c}}$ \\
\hline Each mean represents analyses ofthree independent samples. Statistical differences were analyzed by ANOVA $(\mathrm{P}<0.05)$. Differentl letter superscripts within a row indicate significant
\end{tabular}

differences at $p<0.05$.

\section{Discussion}

Convincing evidence indicates that increased consumption of dietaryantioxidants or vegetables and fruits with antioxidant properties may contribute to the improvement in quality of life by delaying onset and reducing the risk of degenerative diseases associated with aging (Arai et al., 2000). However, owing to differences in their molecular structure, the various antioxidants exhibit substantial differences in effectiveness when used under different processing and handling conditions (Sultana et al., 2007; T urkmen et al., 2005). For example, exposure of food components to temperatures above ambient conditions (during heat processing) is a major cause of detectable changes, not only of nutritional quality, but also of antioxidant activity or scavenger capacity.

The increase in total phenolic content found in short simmered vegetables in the current study when compared to uncooked samples, appears to have a similar mechanism to the ones reported in earlier studies on other vegetables (Shi et al., 1999; Nguyen et al., 2001). Possibilities suggested for the increase in antioxidant activity of some vegetables after aquathermal treatment include: the liberation of high amounts of antioxidant components due to the thermal destruction of cell walls and sub-cellular compartments; suppression of the oxidation capacity of antioxidants by thermal inactivation of oxidative enzymes and production of new non-nutrient antioxidants (for instance Maillard reaction products) (Odukoya et al., 2007; Morales et al., 2002).

Diverse groups of phenolics, being the widest spread secondarymetabolite in plantkingdom, have received much attention as potential natural antioxidant in terms of their ability to act as free radical scavengers and metal chelator (Cao et al., 1997). It has been reported that the antioxidant activity of phenol is mainly due to their redox properties, hydrogen donors and singlet oxygen quenchers (Apak et al., 2007). Thermal treatments increased the bioavailability of polyphenols most likely as a result of a weakening of the plant biomass allowing for greater bioavailability of polyphenols contained inside the cell walls (Ferracane et al., 2008). The phenolic contents are highest in the outer layers of some vegetables and these are extremely exposed to the water. As a consequence total phenolics which are usually stored in vegetables in the pectin or cellulose networks can be released during aquathermal processing, as heat can break the supramolecular structures, liberating the phenolics, especially the glycosides, which react better with the Folin-Ciocalteau reagent (Bunea et al., 2008). 
The trend in the TPC of both uncooked and short simmer extract agrees with that of total flavonoid content in all except $S$. melongena with the lowest phenolic contentand $\mathrm{G}$. latifola having the lowest total flavonoid content. This may be as a result of differences in stability of the bioactive components to heat (Pedraza-Chaverr et al., 2006). Result with similar trend observed with metal chelating compounds found in S. biafrae, DPPH scanvengers in C. argentea, hydroxyl radical scavengers in 0 . gratissimum and $P$. guineense, the total phenolic content in S. biafrae and C. argentea; may be due to the variability in the bioactive components in the vegetables. As opposed to the long simmer aquathermal treatments where antioxidant activity and phenolics of some of the vegetables were lost.

Length of aquathermal treatment did not affect the total phenolic content of $P$. mildbraedii and $C$. argentea, total flavonoid content and reducing power activity of $P$. guineense. Based on the current study, short simmer treatments, compared to other treatments, were the most optimal at increasing the antioxidant activity and phenolics of green leafy vegetables. This increase is possibly due to degradation of biomass.

It is worth noting that cooking generally enhances the scavenging properties of all the vegetables used in this study, this agrees with other report on the effect of cooking on the antioxidant properties of maize, tomatoes and some tropical green leafy vegetables (Dewanto et al., 2002; Dewanto et al., 2002; Adepfegha and Oboh, 2011). The increase in antioxidant activity will not be far fetch from the significantincrease in the antioxidant phytochemicals (polyphenolics) that accompanied cooking, a strong linear relationship exists between TPC and DPPH and TPC and flavonoids. Similar relationships between TPC and DPPH assays have been found by other researchers (Roy et al., 2002; Chew et al., 2008; Sikora et al., 2008; Xu and Chang, 2008).

This shows that phenolic could be the main antioxidant phytochemicals in leafy vegetables. This claim is in agreement with several results where correlation was found between the total phenol content of some plant foods and their antioxidant capacity(T urkmen et al., 2005; Zhang and Hamauzu, 2004). The trend in the hydroxyl radical scavenging ability of both the uncooked, short simmer and long simmer extracts agrees with that of total flavonoids contentwhereas the trend between TPC and hydroxyl radical scavenging properties was low. This shows that flavonoids could be the main phenolics scavenger in the vegetables.

However, loss in DPPH radical scavenging activity in C. argentea and hydroxyl radical scavenging activity in 0 . gratissimum, $P$. guineense and $C$. argentea as a result of extensive thermal treatment in this study may be due to the higher content of thermally unstable flavonoid polyphenolics, such as anthocyanin and vitamins, such as, ascorbic acid in these vegetables (Eitenmiller and Landen, 1999). Moreover, no relationship exists between hydroxyl radical scavenging activity and DPPH scavenging activity, unlike hydroxyl radical which is a laboratory-generated radical, DPPH has the advantage of being unaffected by certain side reactions, such as metal-ion chelation and enzyme inhibition, brought about by various additives (Amarowicz et al., 2004).

For the measurements of the reducing ability, the $\mathrm{Fe}^{3+}-\mathrm{Fe}^{2+}$ transformation was investigated in the presence of the extracts. The reducing capacity of a compound mayas well serve as a significantindicator of its potential antioxidant activity (Apak et al., 2005). The activity of antioxidants has been assigned to various mechanisms such as prevention of chain initiation, binding of transition metal ion catalysts, decomposition of peroxides, prevention of continued hydrogen abstraction, reductive capacity and radical scavenging. Good linear relationship exists between the reducing power and TPC, suggesting the positive influence of the phenolics antioxidant properties of the vegetable. The extracts may possibly consist of hydrophilic polyphenolic compounds that cause the greater reducing power.

\section{CONCLUSION}

Changes in antioxidant activity differ in different vegetables and depend on the different cooking times. These findings indicate that mild and short thermal processing enhances the nutritional value of vegetables by increasing the bio-accessible phenolic content and total antioxidant activity and are against the notion that cooked vegetables have lower nutritional value than fresh vegetables. The effect of cooking on nutrient availability or loss should be investigated in other vegetables and fruits to serve as a database thus providing information on the effects of different cooking times on the antioxidant potential 
of the vegetables. However, in vivo evidence from clinical trial is required in order to integrate test results for meaningful reflection of in vivo status.

\section{REFERENCES}

Adefegha, S.A and Oboh, G. (2013). Cooking enhances the antioxidant properties of some tropical green leafy vegetables. African Journal of Biotechnology, 10(4): 632-639.

Amarowicz, R., Pegg, R.B., Rahimi-Moghaddam, P., Barl, B. and Weil, J.A. (2004). Free-radical scavenging capacity and antioxidant activity of selected plant species from the Canadian prairies. Food Chemistry, 84(4): 551-562.

Apak, R., Güçlü, K., Demirata, B., Ozzürek, M.,.,̧elik, S.E., Bektaşoğlu, B., Berker, K.I. and Özyurt, D. (2007). Comparative evaluation of various total antioxidant capacity assays applied to phenolic compounds with the CUPRAC assay. Molecules, 12(7): 1496-1547.

Apak, R., Güçlü, K., Ozzyürek, M., Karademir, S.E. and Altun, M. (2005). Total antioxidant capacity assay of human serum using copper (II)neocuproine as chromogenic oxidant: the CUPRAC method. Free radical research, 39(9): 949-961.

Arai, Y., Watanabe, S., Kimira, M., Shimoi, K., Mochizuki, R. and Kinae, N. (2000). Dietary intakes of flavonols, flavones and isoflavones by Japanese women and the inverse correlation between quercetin intake and plasma LDL cholesterol concentration. The Journal of nutrition, 130(9): 2243-2250.

Ardestani, A and Yazdanparast, R. (2007). Antioxidant and Free Radical Scavenging Potential of Achillea santolina Extracts. Food Chemistry, 104:21-29.

Bunea, A., Andjelkovic, M., Socaciu, C., Bobis, O., Neacsu, M., Verhé, R. and Camp, J.V. (2008). Total and individual carotenoids and phenolic acids content in fresh, refrigerated and processed spinach (Spinacia oleracea L.). Food Chemistry, 108(2): 649-656.

Cao, G., Sofic, E. and Prior, R.L. (1997). Antioxidant and prooxidant behavior of flavonoids: structure-activity relationships. Free Radical Biology and Medicine, 22(5): 749-760.

Cartea, M.E. Francisco, M., Soengas, P. and Velasco, P. (2010). Phenolic compounds in Brassica vegetables. Molecules, 16(1): 251-280.
Cederbaum, A.., Lu, Y. and Wu, D. (2009). Role of oxidative stress in alcohol-induced liver injury. Archives of toxicology, 83(6): 519-548.

Chew, Y.L., Lim, Y.Y., Omar, M. and Khoo, K.S. (2008). Antioxidant activity of three edible seaweeds from two areas in South East Asia. LWT-Food Science and Technology, 41(6): 1067-1072.

Dewanto, V., Wu, X., Adom, K.K. and Liu, R.H. (2002). Thermal processing enhances the nutritional value of tomatoes by increasing total antioxidant activity. Journal of agricultural and food chemistry, 50(10): 3010-3014.

Dewanto, V., Wu, X. and Liu, R.H. (2002). Processed sweet corn has higher antioxidant activity. Journal of Agricultural and Food Chemistry, 50(17): 4959-4964.

Dinis, T.C., Madeira, V. M. and Almeida, L.M. (1994). Action of phenolic derivatives (acetaminophen, salicylate, and 5-aminosalicylate) as inhibitors of membrane lipid peroxidation and as peroxyl radical scavengers. Archives of biochemistry and biophysics, 315(1): 161-169.

Eitenmiller RR Landen WO. Vitamin Analysis for the Health and Food Sciences. Boca Raton, CRC Press, 1999.

Ferracane, R., Pellegrini, N., Visconti, A, Graziani, G., Chiavaro, E., Miglio, C. and Fogliano, V. (2008). Effects of Different Cooking Methods on Antioxidant Profile, Antioxidant Capacity, and Physical Characteristics of Artichoke. Journal of Agricultural and Food Chemistry, 56: 8601-8608.

Gutowski, M., and Kowalczyk, S. (2013). A study of free radical chemistry: their role and pathophysiological significance. Acta Biochimica Polonica, 60(1): 1-16.

Jagadish, L.K., Krishnan, V.V., Shenbhagaraman, R. and Kaviyarasan, V. (2009). Comparitive study on the antioxidant, anticancer and antimicrobial property of Agaricus bisporus (JE Lange) Imbach before and after boiling. African Journal of Biotechnology, 8(4): 654-661.

Lobo, V., Patil, A., Phatak, A and Chandra, N. (2010). Free radicals, antioxidants and functional foods: Impact on human health. Pharmacognosy Reviews, 4(8): 118-126.

Morales, F.J. and Babbel, M.B. (2002). Antiradical efficiency of Maillard reaction mixtures in a hydrophilic media. Journal of Agricultural and Food Chemistry, 50(10): 2788-2792. 
Moskovitz, J, Yim, M.B. and Chock, P.B. (2002). Free radicals and disease. Archives of Biochemistry and Biophysics. 397(2): 354-359.

Nguyen, M., Francis, D. and Schwart, S. (2001). Thermal isomerisation susceptibility of carotenoids in different tomato varieties. Journal of the Science of Food and Agriculture, 81(9): 910-917.

Odukoya, O.A., Inya-Agha, S.I., Segun, F.I., Sofidiya, M.O. and Ilori, O.O. (2007). Antioxidant Activity of Selected Nigerian Green Leafy Vegetables. American Journal of Food Technology, 2(3): $169-175$.

Oyaizu, M. (1986). Studies on products of browning reaction: antioxidative activity of products of browning reaction prepared from glucosamine. The Japanese Journal of Nutrition and Dietetics, 44(6): 307-315.

Pedraza-Chaverrí, J., Medina-Campos, O.N., ÁvilaLombardo, R., Berenice Zúñiga-Bustos, A. and Orozco-lbarra, M. (2006). Reactive oxygen species scavenging capacity of different cooked garlic preparations. Life sciences, 78(7): 761-770.

Poli, G., Leonarduzi, G., Biasi, F. and Chiarpotto, E. (2004). Oxidative stress and cell signalling. Current Medicinal Chemistry, 11(9): 11631182.

Rahman, K. (2007). Studies on free radicals, antioxidants, and co-factors. Clinical Interventions in Aging, 2(2): 219-236.

Roy, M.K., Takenaka, M., Isobe, S., and Tsushida, T. (2007). Antioxidant potential, anti-proliferative activities, and phenolic contentin water-soluble fractions of some commonly consumed vegetables: Effects of thermal treatment. Food Chemistry, 103(1): 106-114.

Rufino, M.S.M, Alves, R.E., Fernandes, F.A.N. and Brito, E.S. (2010). Free radical scavenging behavior of ten exotic tropical fruits extracts. Food Research International, 44(7): 20722075.

Shi, J., Maguer, M.L., Kakuda, Y., Liptay, A. and Niekamp, F. (1999). Lycopene degradation and isomerization in tomato dehydration. Food Research International, 32(1): 15-21.

Sikora, E., Cieślik, E., Leszczýnska, T., FilipiakFlorkiewicz, A. and Pisulewski, P.M. (2008). The antioxidant activity of selected cruciferous vegetables subjected to aquathermal processing. Food Chemistry, 107(1): 55-59.
Singleton, V.L., Orthofer, R. and Lamuela-Raventos, R.M. (1999). Analysis of Total Phenols and Other Oxidation Substrates and Antioxidants by Means of Folin-Ciocalteu Reagent. Methods in Enzymology. 299: 152-178.

Sultana, B., Anwar, F. and lqbal, S. (2008). Effect of different cooking methods on the antioxidant activity of some vegetables from Pakistan. International Journal of Food Science and Technology, 43(3): 560-567.

Sun, J., Chu, Y.F., Wu, X., and Liu, R.H. (2002). Antioxidant and antiproliferative activities of common fruits. Journal of Agricultural and Food Chemistry, 50(25): 7449-7454.

Turkmen, N., Sari, F., and Velioglu, Y.S. (2005). The effect of cooking methods on total phenolics and antioxidant activity of selected green vegetables. Food chemistry, 93(4): 713-718.

Valko, M., Leibfritz, D., Moncol, J., Cronin, M.T., Mazur, M. and Telser, J. (2007). Free radicals and antioxidants in normal physiological functions and human disease. International Journal of Biochemistry and Cell Biology, 39(1): 44-84.

VanderJagt, D.J., Garry, P.J., and Hunt, W.C. (1986). Ascorbate in plasma as measured by liquid chromatography and by dichlorophenolindophenol colorimetry. Clinical Chemistry, 32(6): 1004-1006.

Vendemiale, G., Grattagliano, I. and Attomare, E. (1999). An update on the role of free radicals and antioxidant defense in human disease. International Journal of Clinical and Laboratory Research, 29: 49-55.

$\mathrm{Xu}, \mathrm{B}$., and Chang, S.K. (2008). Effect of soaking, boiling, and steaming on total phenolic contentand antioxidantactivities of cool season food legumes. Food Chemistry, 110(1): 1-13.

Yang, J., Lin, H. and Mau, J. (2002). Antioxidant properties of several commercial mushrooms. Food Chemistry, 77: 229-235.

Yu, W., Zhao, Y. and Shu, B. (2004). The radical scavenging activities of radix puerariae isoflavonoids: A chemiluminescence study. Food Chemistry, 86: 525-529.

Zhang, D. and Hamauzu, Y. (2004). Phenolics, ascorbic acid, carotenoids and antioxidant activity of broccoli and their changes during conventional and microwave cooking. Food Chemistry, 88(4): 503-509. 